\title{
A new record of Rondonops biscutatus (Reptilia, Sauria, Gymnophthalmidae) from Mato Grosso, Brazil
}

\author{
Arthur Diesel Abegg, ${ }^{1}$ Omar Machado Entiauspe-Neto, ${ }^{2}$ Filipe Pereira Rego dos Santos, ${ }^{3}$ \\ Leandro Malta Borges ${ }^{4}$
}

1 Instituto Butantan, Laboratório Especial de Coleções Zoológicas, Avenida Vital Brasil, 1500, Butantã, CEP 05503-900 São Paulo, SP, Brazil. 2 Universidade Federal do Rio Grande, Instituto de Ciências Biológicas, Laboratório de Vertebrados, Avenida Itália, km 8, CEP 96203-900, Rio Grande, RS, Brazil. 3 Avenida Cristovão Colombo, 462/402 D; CEP 90560-000, Porto Alegre, RS, Brazil. 4 Universidade Federal de Santa Maria, Laboratório de Sistemática, Entomologia e Biogeografia, Avenida Roraima, 1000, CEP 97105-900, Santa Maria, RS, Brazil.

Corresponding author: Arthur Diesel Abegg, arthur_abegg@hotmail.com

\begin{abstract}
Rondonops biscutatus is a Iphisini species known from the southwestern portion of the Brazilian Amazon forest, in the states of Mato Grosso, Pará and Rondônia. In this study, we report the second known locality for the species in Mato Grosso, extending the distribution of the species approximately $545 \mathrm{~km}$.
\end{abstract}

Key words

Vila Rica; geographical distribution; Amazon rainforest.

Academic editor: Ross MacCulloch | Received 5 May 2017 | Accepted 20 May 2017 | Published 10 July 2017

Citation: Abegg AD, Entiauspe-Neto OM, Santos FPR, Borges LM (2017) A new record of Rondonops biscutatus (Reptilia, Sauria, Gymnophthalmidae) from Mato Grosso, Brazil. Check List 13 (4): 7-10. https://doi.org/10.15560/13.4.7

\section{Introduction}

Rondonops Colli et al., 2015 is a recently described genus within the Iphisini clade, which occurs in the Brazilian Amazon Forest and comprises two species: Rondonops biscutatus Colli et al., 2015 and Rondonops xanthomystax Colli et al., 2015.

Although recently described, $R$. biscutatus has been previously cited in past works. Gainsbury and Colli (2003) reported the species as Gymnophthalmidae sp. Hoogmoed et al. (2007) and Garda et al. (2013) reported it as Colobosaura sp. and Gymnophtalmidae sp., respectively (Colli et al. 2015). According to Garda et al. (2013), who studied the effects of microhabitat variation on lizard distribution in a terra firme (non-floodable forests) forest in Guajará-Mirim (Rondônia state), R. biscutatus is associated with sites distant from large trees, with few fallen logs and burrows, less canopy cover, thicker understory, thinner leaf litter, and numerous termite nests.

Rondonops biscutatus presents a wider geographic distribution than $R$. xanthomystax, occurring in the southwestern Amazon Forest, in the states of Mato Grosso, Pará and Rondônia. It is an inhabitant of leaf litter in terra firme, riparian and seasonally flooded forests, as well as in transitional areas between Amazonia and Cerrado (Colli et al. 2015, Moraes et al. 2016). Its distribution encompasses an area of $90.674 .1 \mathrm{~km}^{2}$, of which nearly $55 \%$ is located within protected areas, while about $22 \%$ has been deforested (Ribeiro-Júnior and Amaral 2016). Here, we present a new record for $R$. biscutatus in the state of Mato 

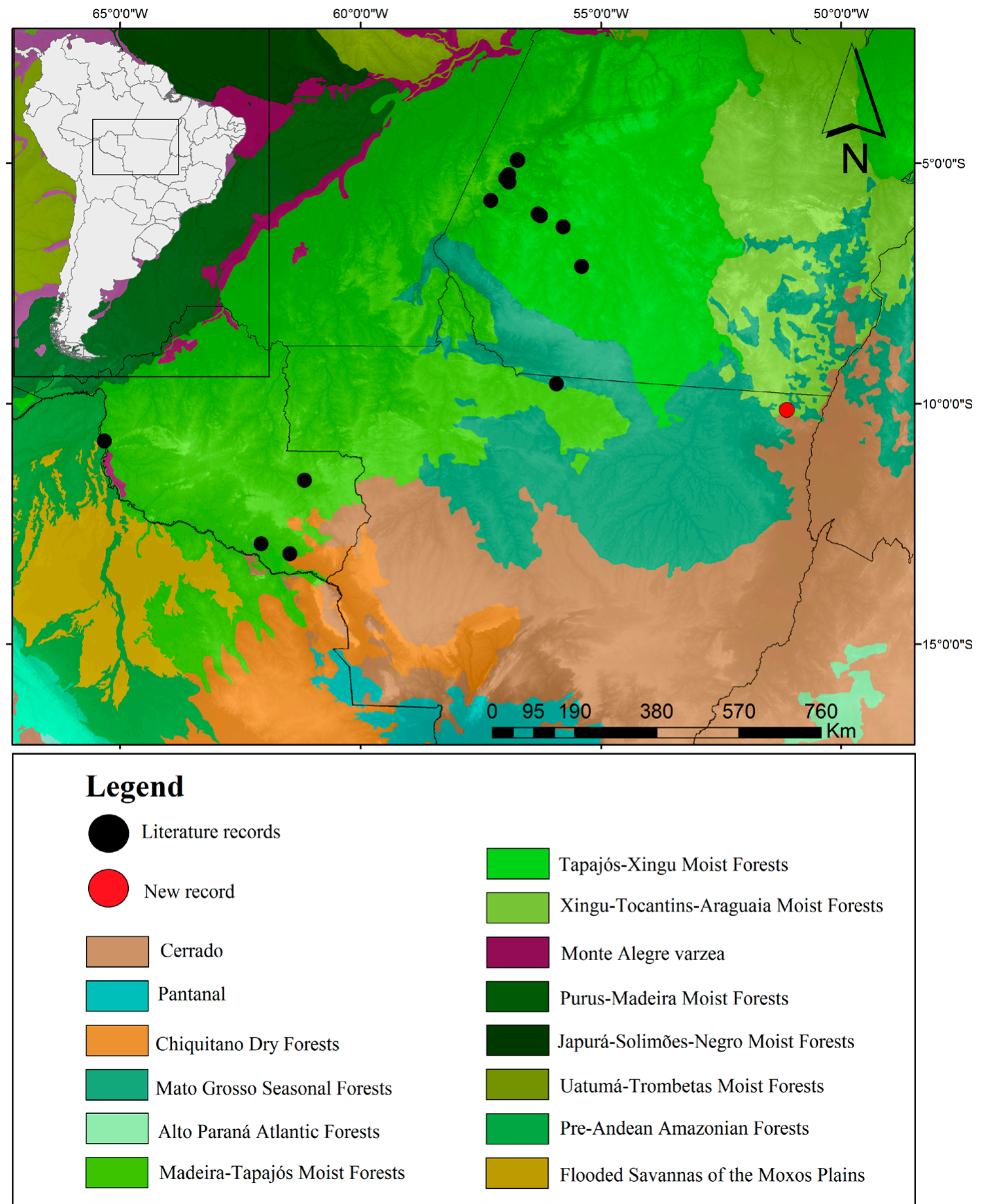

Figure 1. Distribution map for Rondonops biscutatus, with the new record (red circle) in Vila Rica, Mato Grosso, Brazil. Black circles represent literature records.

Grosso, extending its distribution approximately $545 \mathrm{~km}$ east of its nearest locality and establishing the easternmost known locality of occurrence for this species.

\section{Methods}

The new record was made based on a specimen collected at the municipality of Vila Rica $(-10.1258,-051.1369$; 220 m; geodetic datum, WGS84) (Fig. 1), state of Mato Grosso, west-central Brazil, on 9 May 2014, during a faunal monitoring program for the BR-158/MT highway. The individual was captured in a pitfall trap (collecting permit SISBio 2004-53), euthanized and deposited in the herpetological collection of Pontifícia Universidade
Católica do Rio Grande do Sul (Accession number MCP 19465) (Fig. 2).

\section{Results}

The specimen is identified based on morphological analysis using literature data. According to original description (Colli et al. 2015), the genus is morphologically distinctive and easily distinguished from all other genera of Gymnophthalmidae, by having very wide, smooth, and imbricate nuchal scales, arranged in 2 longitudinal and 6-10 transverse rows from nape to brachium level, followed by much narrower, strongly keeled, lanceolate, and mucronate scales. 


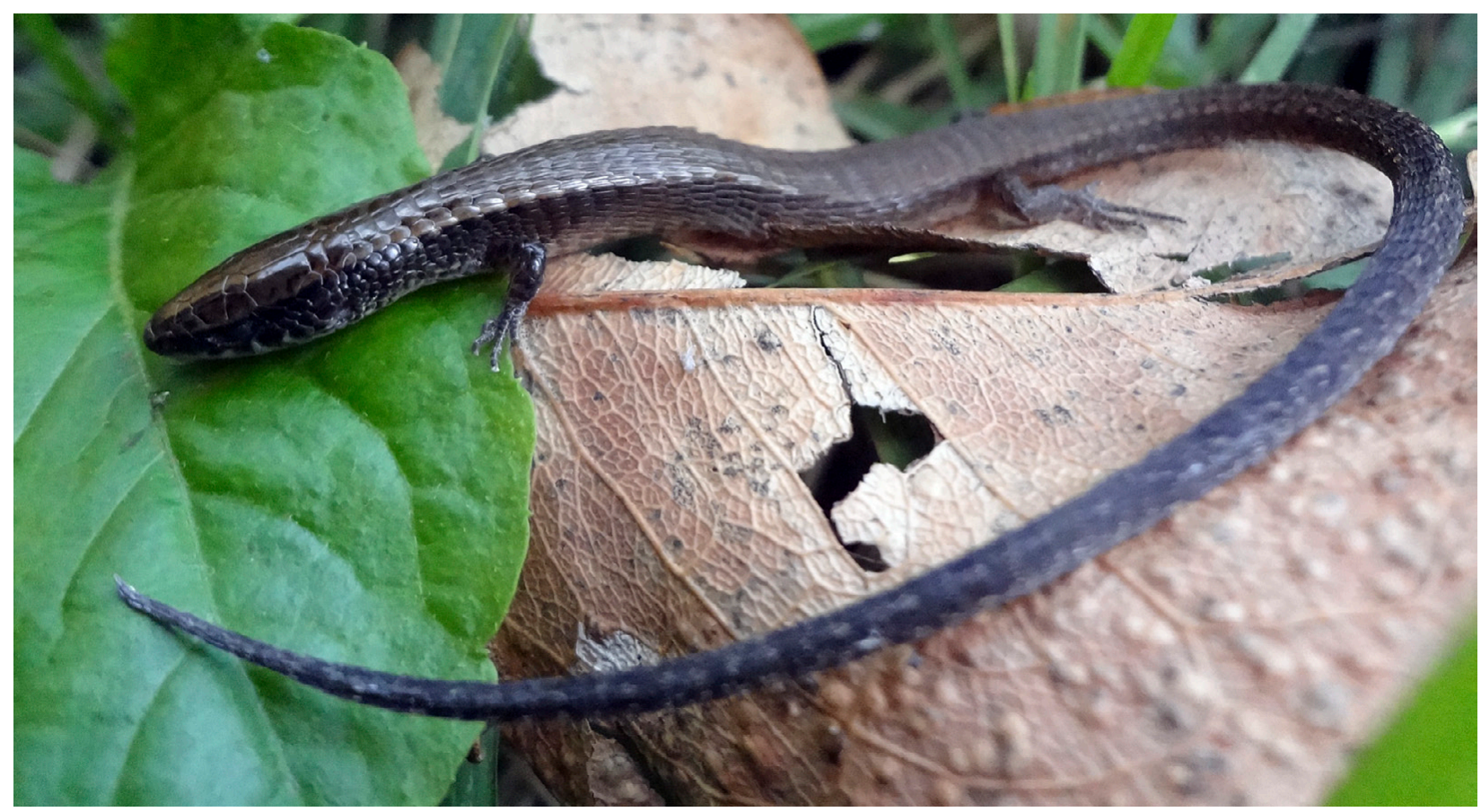

Figure 2. Specimen of Rondonops biscutatus MCP 19465 collected in the municipality of Vila Rica $(-10.1258,-051.1369)$, state of Mato Grosso, Brazil.

Rondonops biscutatus is easily distinguished from $R$. xanthomystax by its supralabials with dark brown pigmentation (versus bright orange and yellow coloration on most of the supralabials, infralabials, and ventral surfaces of head and throat in R. xanthomystax). In addition, scales on sides of neck are smooth in $R$. biscutatus (versus keeled in $R$. xanthomystax). The specimen's morphology is in accordance with the diagnosis presented by Colli et al. (2015) for $R$. biscutatus.

\section{Discussion}

According to Colli et al. (2015), R. biscutatus differs from $R$. xanthomystax in habitat use: $R$. biscutatus is a leaf litter inhabitant, as are most gymnophthalmid lizards, while $R$. xanthomystax occurs in other habitats. In addition, $R$. biscutatus can occur in both forests and areas of open vegetation, while $R$. xanthomystax is restricted to forested areas. Our record of R. biscutatus supports this; Vila Rica is located in a transitional area between Amazonia and Cerrado (Fig. 1) and other specimens (uncollected) were observed in the leaf litter there.

The discovery of a new population of $R$. biscutatus approximately $545 \mathrm{~km}$ from the nearest locality (municipality of Alta Floresta, Mato Grosso), reinforces that this species has a wider geographic distribution than we currently know. However, its distribution encompasses the "arc of deforestation", an expanding area of continuous deforestation, located in southwestern Maranhão, northern Tocantins, Mato Grosso and Rondônia, southern Pará and Amazonas and southeastern Acre (Brooks et al. 2002, Ferreira et al. 2005, Colli et al. 2015). Although a large portion of the $R$. biscutatus occurrence area is within protected areas (Ribeiro-Júnior and Amaral 2016), these populations might be exposed to strong ecological pressures resulting from anthropogenic influence, especially those resulting in changes of natural environments, forest fragmentation, and habitat loss (Ribeiro-Júnior and Amaral 2016).

\section{Acknowledgements}

We are deeply indebted to editor Ross McCulloch and to Marco Antonio de Freitas and Leandro Moraes for kindly reviewing our manuscript. We also thank ICMBIO for the collecting permit. LMB is grateful to National Council for Scientific and Technological Development (CNPq) for financial support.

\section{Authors' Contributions}

FPRS collected the specimen in the field; ADA, OME-N and LMB wrote the manuscript.

\section{References}

Brooks TM, Mittermeier RA, Mittermeier CG, Fonseca GAB, Rylands AB, Konstant WR, Flick P, Pilgrim J, Oldfield S, Magin G, HiltonTaylor C (2002) Habitat loss and extinction in the hotspots of biodiversity. Conservation Biology 16 (4): 909-923. https://doi. org/10.1046/j.1523-1739.2002.00530.x

Colli GR, Hoogmoed MS, Cannatella DC, Cassimiro J, Gomes JO, Ghellere JM, Nunes PMS, Pellegrino KCM, Salerno P, Souza SM, Rodrigues MT (2015) Description and phylogenetic relationships of a new genus and two new species of lizards from Brazilian Amazonia, with nomenclatural comments on the taxonomy of Gymnophthalmidae (Reptilia: Squamata). Zootaxa 4000: 401-427. https://doi.org/10.11646/zootaxa.4000.4.1

Ferreira LV, Venticinque E, Almeida S (2005) O desmatamento na 
Amazônia e a importância das áreas protegidas. Estudos Avançados 19: 157-166. https://doi.org/10.1590/s0103-40142005000100010

Gainsbury AM, Colli GR. 2003. Lizard assemblages from natural cerrado enclaves in southwestern Amazonia: the role of stochastic extinctions and isolation. Biotropica 35 (4): 503-519. https://doi. org/10.1111/j.1744-7429.2003.tb00607.x

Garda AA, Wiederhecker HC, Gainsbury AM, Costa GC, Pyron RA, Vieira GHC, Werneck FP, Colli GR (2013) Microhabitat variation explains local-scale distribution of terrestrial Amazonian lizards in Rondônia, western Brazil. Biotropica 45: 245-252. http://doi. org/10.1111/j.1744-7429.2012.00906.x

Hoogmoed MS, Ribeiro-Júnior MA, Araújo CO (2007) Avaliação do estado de conhecimento da herpetofauna na região da BR-163 no estado do Pará. In: Venturieri A. (Ed) Zoneamento Ecológicoeconômico da Área de Influência da Rodovia BR-163 (CuiabáSantarém). Vol. 2. EMBRAPA Amazônia Oriental, Belém, 143-152.

Moraes LJCL, Pavan D, Barros MC, Ribas CC (2016) The combined influence of riverine barriers and flooding gradients on biogeographical patterns for amphibians and squamates in south-eastern Amazonia. Journal of Biogeography 43: 2113-2124. https://doi. org/10.1111/jbi.12756

Ribeiro-Júnior M, Amaral S (2016) Diversity, distribution, and conservation of lizards (Reptilia: Squamata) in the Brazilian Amazonia. Neotropical Biodiversity 2: 195-421. https://doi.org/10.1080/237 66808.2016 .1236769 